\title{
microRNA response elements-regulated TRAIL expression shows specific survival-suppressing activity on bladder cancer
}

Youguang Zhao ${ }^{{ }^{*+}}$, Ying $\mathrm{Li}^{2+}$, Liang Wang ${ }^{1}$, Hang Yang ${ }^{1}$, Qingtang Wang ${ }^{1}$, Haiyan $\mathrm{Qi}^{3}$, Shadan $\mathrm{Li}^{1}$, Peng Zhou ${ }^{1}$, Ping Liang ${ }^{1}$, Qiwu Wang ${ }^{1}$ and Xiaowei $\mathrm{Li}^{1}$

\begin{abstract}
Background: Bladder transitional cell carcinoma greatly threatens human health all over the world. Tumor necrosis factor-related apoptosis-inducing ligand (TRAIL) shows a strong apoptosis-inducing effect on a variety of cancer cells including bladder cancer. However, adenovirus-mediated TRAlL expression still showed cytotoxicity to normal cells mainly due to lack of tumor specificity.

Methods: To solve the problem, we applied miRNA response elements (MREs) of miR-1, miR-133 and miR-218 to confer TRAIL expression with specificity to bladder cancer cells.

Results: Expression of miR-1, miR-133 and miR-218 was greatly decreased in bladder cancer than normal bladder tissue. Luciferase assay showed that application of the 3 MREs was able to restrain exogenous gene expression to within bladder cancer cells. Subsequently, we constructed a recombinant adenovirus with TRAIL expression regulated by MREs of miR-1, miR-133 and miR-218, namely Ad-TRAIL-MRE-1-133-218. QPCR, immunoblotting and ELISA assays demonstrated that Ad-TRAIL-MRE-1-133-218 expressed in bladder cancer cells, rather than normal bladder cells. The differential TRAIL expression also led to selective apoptosis-inducing and growth-inhibiting effect of Ad-TRAIL-MRE-1-133-218 on bladder cancers. Finally, bladder cancer xenograft in mouse models further confirmed that Ad-TRAIL-MRE-1-133-218 effectively suppressed the growth of bladder cancers.
\end{abstract}

Conclusions: Collectively, we demonstrated that MREs-based TRAIL delivery into bladder cancer cells was feasible and efficient for cancer gene therapy.

Keywords: Bladder cancer, Adenovirus, miRNA, Specificity, TRAIL

\section{Background}

Among the most common malignant cancers, bladder transitional cell carcinoma severely risks health of the people on the earth [1]. Downregulation of certain tumor suppressor genes was documented to largely contribute to initiation, progression, invasion and metastasis of bladder cancer [2]. Therefore, gene therapy is a reasonable strategy for bladder cancer treatment and many reports have confirmed its feasibility and effectiveness $[3,4]$.

\footnotetext{
* Correspondence: zhaoyg717@163.com

${ }^{\dagger}$ Equal contributors

'Department of Urology, General Hospital of Chengdu Military Area Command of Chinese PLA, Chengdu 610083, Sichuan Province, People's Republic of China

Full list of author information is available at the end of the article
}

Tumor necrosis factor-related apoptosis-inducing ligand (TRAIL) has attracted much attention due to its specific induction of apoptosis in various types of cancer cells by binding death receptors and activating mitochondria-independent signal transduction pathway $[5,6]$. Like many other cancer types, adenovirus-mediated TRAIL therapy was well demonstrated to inhibit the survival of bladder cancer cells [7-12]. More intriguingly, extensive DR4 and DR5 expressions of bladder cancer in patients ensure its responsiveness to TRAIL in future clinical treatment [13].

Cytotoxicity to normal cells, however, seriously hurdles the clinical application of adenoviral vector for cancer gene therapy, since adenoviral vector lacks the ability to discriminate cancer and normal cells. To confer

\section{Biomed Central}


adenovirus with bladder cancer specificity, researchers developed many strategies including employing cancerspecific promoter. Although UP II promoter has been used to specifically drive TRAIL expression in bladder cancer cells, more novel strategies are needed to prevent the cytotoxicity of adenovirus-based gene therapy to normal cells [14-16].

Differential expression profile of miRNAs has been widely reported between bladder cancer and normal cells [17]. Decreased expression level of certain miRNAs allows the introduced genes specifically expressed in bladder cancer cells by inserting their miRNA response elements (MREs) following the opening reading frames. So far, no groups have tested the feasibility and effectiveness of this MREs-based strategy for bladder cancerspecific gene therapy.

Here, we intended to identify suitable MREs for bladder cancer specific adenovirus-mediated TRAIL expression from the miRNAs with downregulated expression in bladder cancer, including miR-1 [18-21], miR-99a [22], miR-100 [23], miR-101 [24,25], miR-125b [23,26,27], miR133a [18,20,21,23,28-30], miR-143 [22,23,31-33], miR-145 [21,23,29-31,34], miR-195-5p [35], miR-199a-3p [36], miR-200 [37,38], miR-203 [39,40], miR-205 [37], miR-218 [21,41], miR-490-5p [42], miR-493 [43], miR-517a [44], miR-574-3p [45], miR-1826 [46] and let-7c [42].

\section{Methods}

\section{Primary culture}

We employed primary cultures derived from bladder transitional carcinoma and normal bladder mucosal cells (BMC) in this study. For the culturing of bladder cancer, the samples were obtained with written informed consent from all patients according to protocols approved by Ethical Review Board in General Hospital of Chengdu Military Area Command of Chinese PLA (Chengdu, China). All patients underwent surgical resection of bladder carcinoma at Department of Urology, General Hospital of Chengdu Military Area Command of Chinese PLA (Chengdu, China). Bladder cancer samples were sheared into small pieces, followed by mechanical manipulation to obtain single cell suspension. The primary cultures were maintained in DMEM supplemented with $15 \%$ FBS.

For primary BMC culture, the samples were obtained from 8 patients that underwent cystoscopic examination of asymptomatic haematuria (The biopsies were not malignant revealed by histopathological results). The previously described procedures that have been approved by Ethical Review Board in General Hospital of Chengdu Military Area Command of Chinese PLA (Chengdu, China) was followed to establish the primary BMC culture [47]. The BMCs were immortalized using adenoviral vector, Adeno-SV40 (Applied Biological Materials Inc.,
Canada), according to the manufacturer's instructions. All the patients approved the application of their samples for this study.

\section{Construction of adenoviral vectors}

Ad-EGFP and Ad-TRAIL were preserved in our laboratory. We constructed Ad-TRAIL-MRE-1-133-218 as follows. A DNA fragment was synthesized (5' -ACAAACACCACATT CCAACAAACACCACATTCC.

AACAAACACCGGACCAAAACAAACACCGGAC CAAAACAAACACCAAGCACAAACAAACACCAA GCACAA-3'), which contained two copies of miR-1 MREs, two copies of miR-133 MREs and two copies of miR-218 MREs. This fragment was released from the temporary vector by $E c o R V$ and then inserted into pShuttle-CMV-TRAIL at the same site, generating pShuttle-CMV-TRAIL-MRE-1-133-218. This plasmid was subsequently cotransfected into HEK-293 cells with pAdEasy. After plague purification for three times and PCR-based identification, adenoviruses were harvested and then purified with the $\mathrm{CsCl}$ gradient centrifugation. The involved adenoviruses were titrated with TCID $_{50}$ method on HEK-293 cells and represented as plaqueforming units per milliliter (pfu/ml) [48]. The adenovirus was designated as Ad5-TRAIL-MRE-1-133-218. The structures of these adenoviruses were shown in Figure 1a.

\section{Cell line cultures}

Human bladder transitional cell carcinoma cell line T24 and RT-4 were both purchased from the American Type Culture Collection (Manassas, VA) and were grown in McCoy's 5a Medium Modified (Life Technologies, Rockville, MD) supplemented with $10 \%$ (v/v) fetal bovine serum (Life Technologies, Rockville, MD). Human endothelial cells HUV-EC-C and normal liver cells L-02 were obtained from Shanghai Cell Collection (Shanghai, China). HUV-EC-C and L-02 cells were cultured using DMEM media supplemented with $10 \%(\mathrm{v} / \mathrm{v})$ fetal bovine serum. All media was supplemented with $4 \mathrm{mM}$ glutamine, 100 units $/ \mathrm{mL}$ penicillin and $100 \mu \mathrm{g} / \mathrm{ml}$ streptomycin. All cells in this experiment were cultured under a $5 \% \mathrm{CO}_{2}$ and humidified atmosphere at $37^{\circ} \mathrm{C}$.

\section{Quantitative PCR (qPCR)}

Total RNA was extracted from 14 bladder cancer samples with Trizol solution (Sigma-Aldrich, MO) and pooled as one group for subsequent experiments. Another pool of RNA was also obtained from 8 normal bladder mucosal tissues according to the same protocol. Also, T24, RT-4, HUV-EC-C and L-02 cells were processed for extracting RNA with Trizol solution. Reverse transcription reaction was subsequently performed with $\mathrm{TaqMan}^{\circledR}$ MicroRNA Reverse Transcription Kit (Applied Biosystems) according 


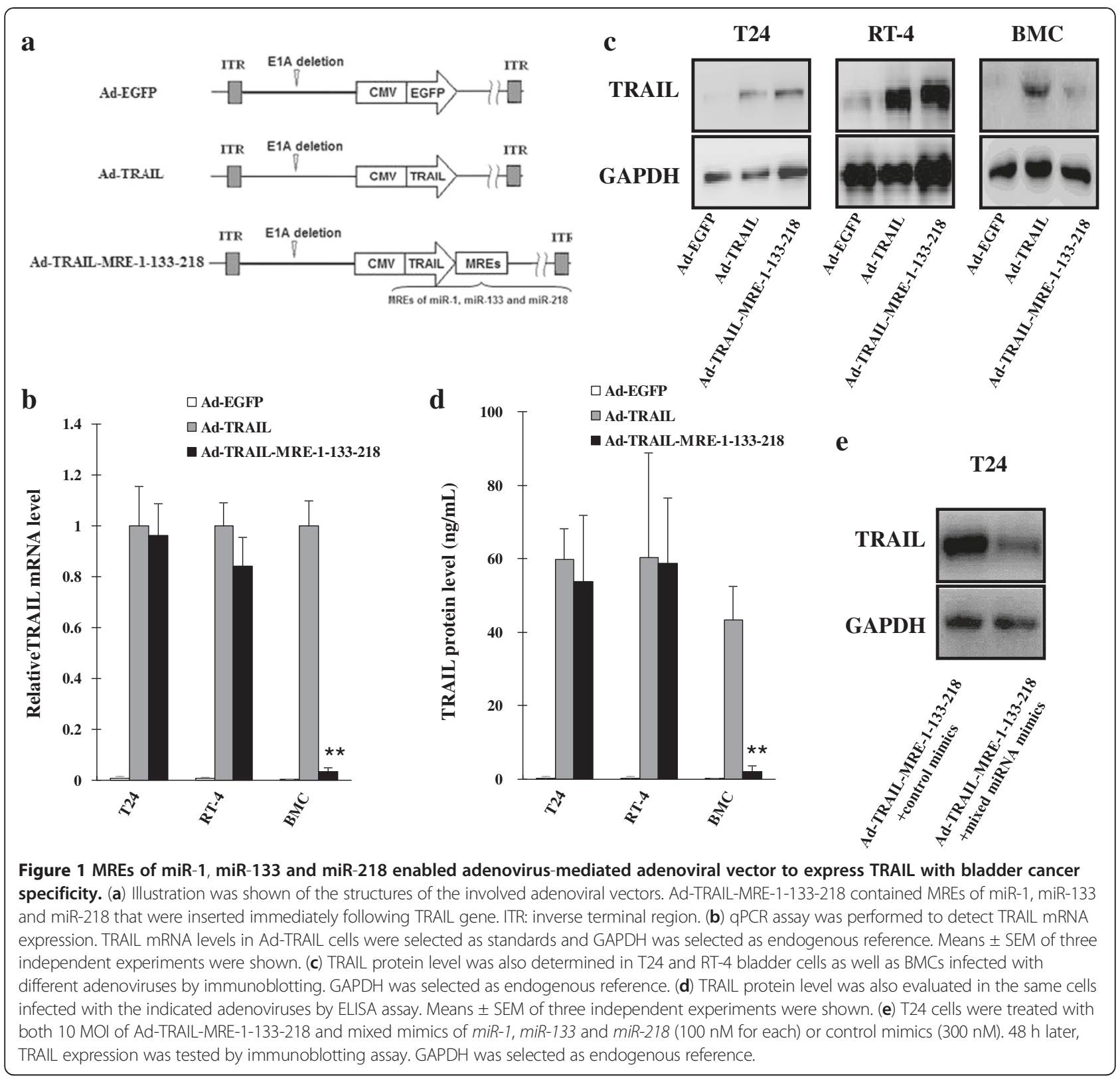

to the manufacturer's instructions. qPCR was finally performed with TaqMan ${ }^{\circledR} 2 \times$ Universal PCR Master Mix (Applied Biosystems) on CFX96 ${ }^{\mathrm{TM}}$ Real-Time PCR Detection System (Bio-Rad Laboratories, CA) supplied with analytical software.

$4 \times 10^{4}$ cells were cultured in each well of 6-well plates. TRAIL mRNA abundance was determined in Ad-TRAIL-MRE-1-133-218-infected cells after treated with $10 \mathrm{MOI}$ of adenoviruses. After 48h, cells were lysed for RNA extraction and then inversely transcribed into cDNAs with Rever Tra Ace qPCR RT Kit (Toyobo, Japan) according to the manufacturer's instructions. qPCR was performed with SYBR premix Ex Taq (TaKaRa) on CFX96 ${ }^{\mathrm{TM}}$ Real-Time PCR Detection System
(Bio-Rad Laboratories, CA) supplied with analytical software.

\section{Immunoblotting assay}

Protein in adenovirus-infected cells was quantified with immunoblotting assay. $3.5 \times 10^{5}$ cells were cultured in each well of 6-well plates. $10 \mathrm{MOI}$ of adenoviruses were added to cell cultures. Proteins were lyzed with M-PER ${ }^{\circledR}$ Mammalian Protein Extraction Reagent (Thermo Scientific, IL) after $48 \mathrm{~h}$, separated using polyacrylamide gel electrophoresis and transferred onto $0.45 \mu \mathrm{m}$ nitrocellulose membranes. $5 \%$ fat-free dry milk was used for blocking. The membrane was then incubated with specific primary antibodies for $6 \mathrm{~h}$. The membrane was incubated 
with corresponding secondary antibody and then with SuperSignal West Dura Extended Duration Substrate (Thermo Scientific, IL).

\section{TRAIL determination by ELISA assay}

We performed ELISA assay to evaluate the secreted TRAIL protein in media. Briefly, $3.5 \times 10^{5}$ cells were cultured in each well of 6-well plates. $10 \mathrm{MOI}$ of adenoviruses were added to cell media. After 48h, two-antibody sandwich ELISA was applied to determine human TRAIL expression level in the supernatant of cells. The involved antibodies are monoclonal mouse anti-human TRAIL antibody (R\&D Systems), peroxidase-conjugated rabbit anti-goat IgG (H\&L) and goat anti-human TRAIL antibody (R\&D Systems). The absorbance was assessed at a $450 \mathrm{~nm}$ wavelength.

\section{miRNA mimics treatment}

$m i R-1, m i R-133, m i R-218$ and control mimics were synthesized by GenePharma (Shanghai, China). T24 and RT-4 cells were transfected with $300 \mathrm{nM}$ control mimic

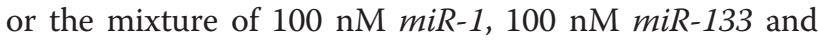
$100 \mathrm{nM}$ miR-218.

\section{FACS analysis on apoptotic rates}

$3.5 \times 10^{5}$ cells were cultured in each well of 6 -well plates. After $24 \mathrm{~h}$, the cells were infected with adenoviruses of 10 MOI. After 48h, the cells were stained with Annexin V-PE Apoptosis Detection Kit (Biovision, CA) based on the manufacturer's instructions. The percentages of apoptotic cells were examined with FACS analysis.

\section{Luciferase assay}

The synthesized DNA constructs, which contains two copies of indicated MREs, were inserted into the XhoI and NotI sites of psiCheck2 vectors (Promega, WI) to construct recombinant luciferase reporter (psiCheck2-*). The involved MREs sequences in our study were described in detail in Table 1 .

$4 \times 10^{4}$ cells were cultured in each well of 24-well plates. After transfecting T24, RT-4 and BMCs with the above plasmids, cells were processed with lysis buffer, and subsequently, luciferase activities were assessed with the Dual-Luciferase reporter system (Promega, WI) according to the manufacturers' instructions.

\section{Cell viability assay}

$1 \times 10^{4} \mathrm{~T} 24$ and RT- 4 cells, $1.5 \times 10^{4}$ primary bladder cancer cells or $2 \times 10^{4}$ BMCs were cultured in each well of 96well plates. Adenoviruses of indicated MOIs were added to cell cultures. After $6 \mathrm{~d}, 50 \mu \mathrm{l}$ of MTT $(1 \mathrm{mg} / \mathrm{ml})$ was added, and $4 \mathrm{~h}$ later, MTT-containing media was replaced with $150 \mu \mathrm{l}$ of DMSO. The spectrophotometric absorbance was assessed on a model 550 microplate reader (Bio-Rad
Table 1 MiRNA response elements (MREs) for bladder cancer-specific downregulated miRNAs

\begin{tabular}{|c|c|}
\hline miRNA & primer sequences \\
\hline \multirow{2}{*}{$\operatorname{miR}-1$} & $\begin{array}{l}\text { Forward: 5'-TCGAGACAAACACC } \\
\text { ACATTCCAACAAACACCACATTCCAACAAACACCGC-3' }\end{array}$ \\
\hline & $\begin{array}{l}\text { Reverse: 5'-GGCCGCGGTGTTTGT } \\
\text { TGGAATGTGGTGTTTGTTGGAATGTGGTGTTTGTC-3' }\end{array}$ \\
\hline \multirow{2}{*}{ miR-99a } & $\begin{array}{l}\text { Forward: 5'-TCGAGACAAACACC } \\
\text { TACGGGTACAAACACCTACGGGTACAAACACCGC-3' }\end{array}$ \\
\hline & $\begin{array}{l}\text { Reverse: 5'-GGCCGCGGTGTITGT } \\
\text { ACCCGTAGGTGTTGTACCCGTAGGTGTTTGTC-3' }\end{array}$ \\
\hline \multirow{2}{*}{ miR-101 } & $\begin{array}{l}\text { Forward: 5'-TCGAGACAAACACC } \\
\text { GTACTGTACAAACACCGTACTGTACAAACACCGC-3' }\end{array}$ \\
\hline & $\begin{array}{l}\text { Reverse: 5'-GGCCGCGGTGTTTGT } \\
\text { ACAGTACGGTGTTTGTACAGTACGGTGTTTGTC-3' }\end{array}$ \\
\hline \multirow{2}{*}{$\operatorname{miR}-133$} & $\begin{array}{l}\text { Forward: 5'-TCGAGACAAACACC } \\
\text { GGACCAAAACAAACACCGGACCAAAACAAACACCGC-3' }\end{array}$ \\
\hline & $\begin{array}{l}\text { Reverse: 5'-GGCCGCGGTGTTGT } \\
\text { ITTGGTCCGGTGTITGTITTGGTCCGGTGTITGTC-3' }\end{array}$ \\
\hline \multirow{2}{*}{ miR-218 } & $\begin{array}{l}\text { Forward: 5'-TCGAGACAAACACC } \\
\text { AAGCACAAACAAACACCAAGCACAAACAAACACCGC-3' }\end{array}$ \\
\hline & $\begin{array}{l}\text { Reverse: 5'-GGCCGCGGTGTTGT } \\
\text { ITGTGCTIGGTGTTGTITGTGCTTGGTGTTTGTC-3' }\end{array}$ \\
\hline \multirow{2}{*}{ miR-490-5p } & $\begin{array}{l}\text { Forward: 5'-TCGAGACAAACACC } \\
\text { ATCCATGACAAACACCATCCATGACAAACACCGC-3' }\end{array}$ \\
\hline & $\begin{array}{l}\text { Reverse: 5'-GGCCGCGGTGTTTGT } \\
\text { CATGGATGGTGTTTGTCATGGATGGTGTTTGTC-3' }\end{array}$ \\
\hline \multirow{2}{*}{ miR-493 } & $\begin{array}{l}\text { Forward: 5'-TCGAGACAAACACC } \\
\text { ACCTTCAACAAACACCACCTCAACAAACACCGC-3' }\end{array}$ \\
\hline & $\begin{array}{l}\text { Reverse: 5'-GGCCGCGGTGTTTGT } \\
\text { TGAAGGTGGTGTTTGTGAAGGTGGTGTTTGTC-3' }\end{array}$ \\
\hline \multirow{2}{*}{ miR-517a } & $\begin{array}{l}\text { Forward: 5'-TCGAGACAAACACC } \\
\text { TGCACGACACAACACCTGCACGAACAAACACCGC-3' }\end{array}$ \\
\hline & $\begin{array}{l}\text { Reverse: 5'-GGCCGCGGTGTTGGT } \\
\text { TCGTGCAGGTGTTTGTTCGTGCAGGTGTTTGTC-3' }\end{array}$ \\
\hline
\end{tabular}

The underscored sequences indicated MREs of miR-1, miR-99a, miR-101, miR-133 and miR-218, miR-490-5p, miR-493 and miR-517a.

Laboratories, Hercules, CA) at $570 \mathrm{~nm}$ with a reference wavelength of $655 \mathrm{~nm}$. Cell viability $=$ absorbance value of infected cells / absorbance value of uninfected control cells.

\section{Animal experiments}

Procedures for animal experiments were all approved by the Committee on the Use and Care on Animals in Qingdao Municipal Hospital (Qingdao, China).

$2 \times 10^{6} \mathrm{~T} 24$ cells were inoculated at the left flanks of 5week-old female BALB/c nude mice (Institute of Animal Center, Chinese Academy of Sciences, Shanghai, China). When tumors reached 7-9 $\mathrm{mm}$ in diameter, 24 mice were equally assigned into 4 groups $(n=6) .100 \mu \mathrm{L}$ of PBS with or without $2 \times 10^{8}$ pfu of Ad-EGFP, Ad-TRAIL and AdTRAIL-MRE-1-133-218 was directly administrated into tumors by injection, respectively. The administrations were performed every other day for five times with a total dosage of $1 \times 10^{9}$ pfu of adenoviruses. 
T-24 cancer xenograft was established by incubating $1.5 \times 10^{6}$ cells at the right flanks of 5 -week-old female $\mathrm{BALB} / \mathrm{c}$ nude mice. 24 mice were equally divided into 4 groups $(n=6)$. The doses of used adenoviruses and injection procedures were the same as those on T24 tumor xenograft.

We periodically measured tumor diameter using calipers. Tumor volume $\left(\mathrm{mm}^{3}\right)=$ maximal length $(\mathrm{mm}) \times$ perpendicular width $(\mathrm{mm})^{2} / 2$.

\section{Liver function evaluation}

To evaluate the hepatoxicity induced by adenovirus treatment, BALB/c mice $(n=5)$ were intravenously injected with $1 \times 10^{9}$ pfu of indicated adenoviruses every other day for five times. On day 11, their blood (600 $\mathrm{mL} / \mathrm{mice}$ ) was harvested by cardiac puncture, followed by being incubated with $12 \mathrm{U}$ of heparin. Alanine aminotransferase (ALT) levels in blood were detected at the Clinical Laboratory, Qingdao Manucipal Hospital (Qingdao, China).

\section{Histological staining}

On day 7 after adenovirus injection, one mouse was sacrificed from each group and its tumor, brain and liver were collected and fixed according to the routine procedures. Histological staining was then performed on formalin-fixed, paraffin-embedded tumor, brain and liver tissue sections using the streptavidinbiotin peroxidase complex method. Anti-TRAIL antibody (Santa Cruz Biotechnology, CA) was used to specifically recognize TRAIL protein. The sections were finally counterstained with hematoxylin.

\section{Statistical analysis}

The statistical tests in this manuscript were two-tailed student's t-test. Differences were considered as statistically significant (*) when $\mathrm{P}<0.05$ and statistically very significant $(* *)$ when $\mathrm{P}<0.01$.

\section{Results}

The expression levels of 8 miRNAs were greatly reduced in bladder cancer cells

To experimentally identify downregulated miRNAs in cancerous tissues derived from bladder epithelium, we studied miRNA expression profiles in 14 bladder cancer samples. qPCR assay showed that expression levels of all the tested miRNAs were decreased in bladder cancer cells in comparison with 8 noncancerous bladder tissue. Among them, miR-1, miR-99a, miR-101, miR-133a, miR-218, miR-490$5 p, m i R-493$ and $m i R-517 a$ had reduction of greater than $90 \%$ in their expression level $(\mathrm{P}<0.01)$ (Figure 2a). Also, we detected the expression levels of $m i R-1, m i R-99 a, m i R-101$, $m i R-133 a, m i R-218, m i R-490-5 p, m i R-493$ and $m i R-517 a$ in T24 and RT-4 bladder cancer cell lines. Consistently, their levels were reduced in the tested cell lines (Additional file 1: Figure S1). The differential expression profile of miRNAs ensured the possibility of utilizing these miRNAs to specifically express genes of interests in bladder cancer cells.

\section{Application of MREs of miR-1, miR-133 and miR-218 restrained exogenous gene expression within bladder cancer cells.}

To assess if MREs of $m i R-1, m i R-99 a, m i R-101, m i R-133 a$, $m i R-218, m i R-490-5 p, m i R-493$ and miR-517a could be used for bladder cancer-specific delivery of exogenous genes, we constructed a series of reporter plasmids containing luciferase regulated by their MREs. The data revealed that luciferase expression was only slightly affected in bladder cancer cells transfected with the reporter plasmids that were regulated by MREs of $m i R-1$, $m i R-101, m i R-133 a, m i R-218$ and $m i R-490-5 p$ (Figure 2b). Furthermore, inhibitory effect on luciferase expression was greater than $80 \%$ in bladder mucosal cells (BMCs) when MREs of $m i R-1, m i R-133 a$ and $m i R-218$ were used $(\mathrm{P}<0.01)$ (Figure $2 \mathrm{~b})$. Furthermore, HUV-EC-C and normal liver cells L-02 have been shown to have much higher expression level of $m i R-1$, miR-133a and miR-218 than bladder cancer samples (Additional file 2: Figure S2).

\section{Bladder cancer-specific expression of TRAIL genes was achieved by employing MREs of miR-1, miR-133 and} miR-218

To confirm if combined application of MREs of $m i R-1, m i R-$ 133 and miR-218 conferred TRAIL expression with bladder cancer specificity, we simultaneously inserted the 3 MREs immediately following TRAIL-encoding open reading frame on adenoviral vectors (Figure 1a). qPCR assay showed that the modified adenovirus, Ad-TRAIL-MRE-1-133-218, had a similar level of TRAIL gene to that of Ad-TRAIL in bladder cancer while TRAIL expression was greatly suppressed in Ad-TRAIL-MRE-1-133-218-infected BMC (Figure 1b). Immunoblotting and ELISA assays also confirmed that Ad-TRAIL-MRE-1-133-218 infection resulted in TRAIL expression with a comparative level with Ad-TRAIL, but almost no TRAIL expression was detected in normal bladder mucosal cells infected with Ad-TRAIL-MRE-1133-218 (Figure 1c and d).

To confirm MRE-regulated TRAIL expression was dependant on the level of corresponding miRNAs, AdTRAIL-MRE-1-133-218-infected T24 cells were treated with mixed mimics of $m i R-1, m i R-133$ and $m i R-218$. Elevated expression level of these miRNAs led to a great reduction in TRAIL expression in bladder cancer cells (Figure 1e).

The above results verified that simultaneous application of MREs of $m i R-1, m i R-133$ and $m i R-218$ conferred adenovirus-mediated TRAIL expression with bladder cancer specificity. 


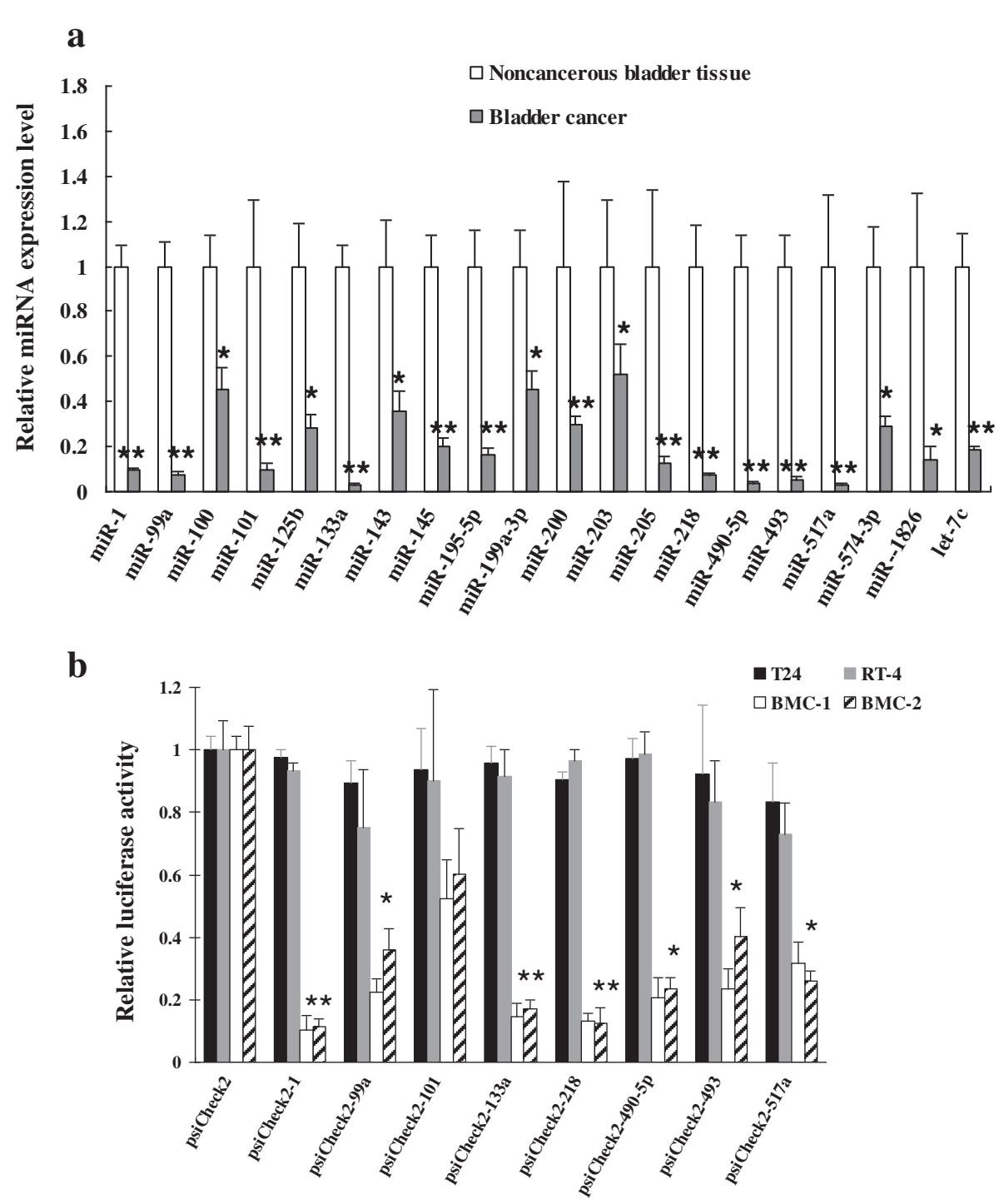

Figure 2 MREs-regulated expression of exogenous gene in bladder cancer cells. (a) Expression of different miRNAs was detected in the pooled 14 bladder cancer and 8 normal bladder mucosal tissues. miRNA level in noncancerous bladder tissue was regarded as standard and U6 was selected as endogenous reference. Means \pm SEM of three independent experiments were shown. (b) LuciferBMCase activity was quantified in T24 and RT-4 bladder cells as well as s that were transfected with luciferase reporter plasmids. The luciferase activity in these cells transfected with psiCheck2 was used as standard. Means \pm SEM of three independent experiments were shown.

MREs-regulated adenovirus-mediated TRAIL expression specifically activated extrinsic apoptotic pathway in bladder cancer cells

As a well-known proapoptotic protein, TRAIL induced apoptosis in a variety of cancer types through activating extrinsic apoptotic pathway. Therefore, we investigated if normal bladder mucosal cells evaded the apoptosis induced by TRAIL expression by Ad-TRAIL-MRE-1133-218. FACS analysis showed that apoptosis took place selectively in bladder cancer cells, rather than normal bladder cells, when Ad-TRAIL-MRE-1-133-218 was employed. In contrast, Ad-TRAIL induced apoptosis both in bladder cancerous and normal cells. In addition, there was no significant difference in apoptotic rate between Ad-TRAIL- and Ad-TRAIL-MRE-1-133-218treated bladder cancer cells, suggesting no impairment of apoptosis-inducing capacity caused by this modification (Figure 3a).

We subsequently examined the activation of extrinsic apoptosis pathway in T24, RT-4 and BMC cells by immunoblotting assay. The data showed that caspase- 8 was cleaved in Ad-TRAIL and Ad-TRAIL-MRE-1-133-218infected bladder cancer cells as well as Ad-TRAIL-infected BMCs. However, this cleavage did not take place in Ad5-TRAIL-MRE-1-133-218-treated normal bladder mucosal cells (Figure 3b). Similarly, cleavages of caspase-3 
and PARP proteins were also observed in the same patterns as caspase-8, suggesting extrinsic apoptotic pathway was selectively activated in bladder cancer cells when Ad5-TRAIL-MRE-1-133-218 was used (Figure 3b).

\section{Ad-TRAIL-MRE-1-133-218 decreased the survival of bladder} cancer cells rather than normal bladder mucosal cells

We next investigated the viability of bladder cancer cells and BMCs with MTT assay, when Ad-EGFP, Ad-TRAIL and Ad-TRAIL-MRE-1-133-218 were added to the indicated cell cultures. The data revealed that Ad-TRAIL-MRE-1-133-218 had a comparative tumor-suppressing capacity on T24 and RT-4 bladder cancer cells as well as primary bladder carcinoma cells with Ad-TRAIL (Figure 3c). However, Ad-TRAIL had cytotoxicity to both cancerous and normal bladder cells. In contrast, administration of Ad-TRAIL-MRE-1133-218 did not affect the survival of BMCs.
Collectively, we proved that Ad-TRAIL-MRE-1-133218 inhibited the viability of bladder cancer cells without significant cytotoxicity to normal cells.

\section{Ad-TRAIL-MRE-1-133-218 suppressed the growth of} bladder cancer xenograft in mouse models

Next, we intended to further investigate the suppressive action of Ad-TRAIL-MRE-1-133-218 on bladder cancer xenograft using mouse models. T24 and RT-4 bladder cancer cells were used to establish the tumor xenografts. We periodically recorded the growth of these bladder cancer xenografts when Ad-EGFP, Ad-TRAIL and AdTRAIL-MRE-1-133-218 were administered. The data demonstrated that Ad-TRAIL and Ad-TRAIL-MRE-1-133218 had a similar growth-inhibiting effect on both T24 and RT-4 bladder cancers (Figure 4a and b). The animal experiments consistently demonstrated that MREs-

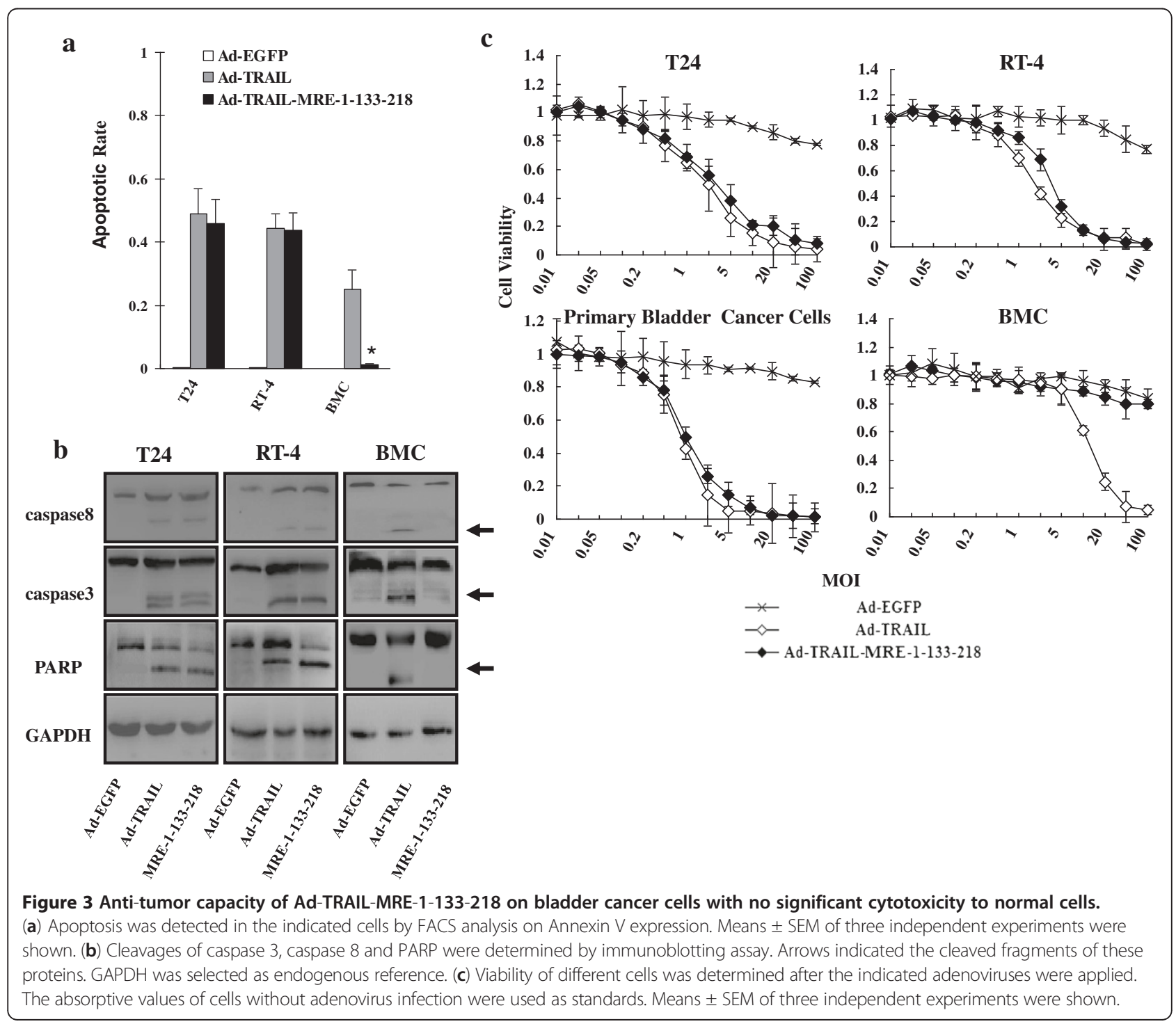



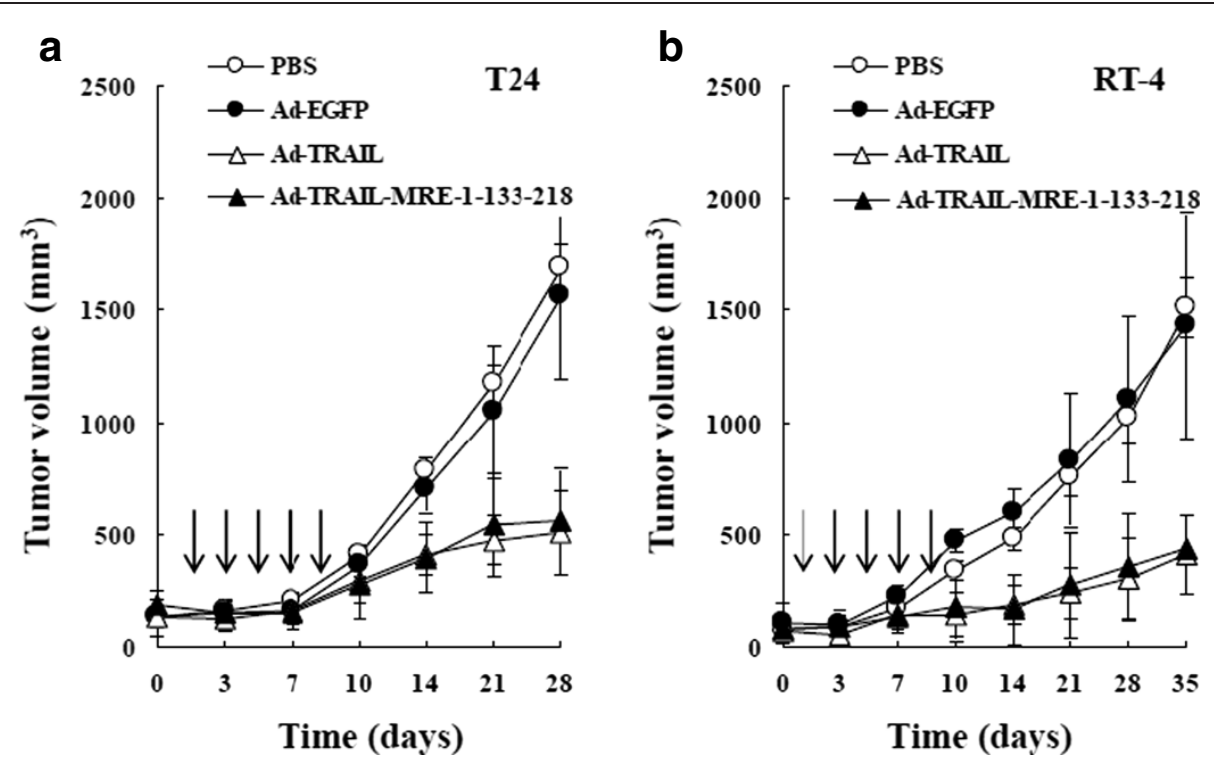

C

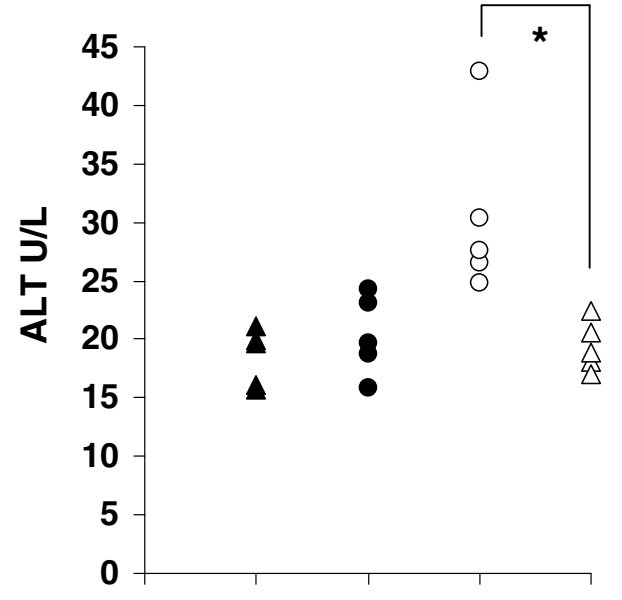

$\triangle$ PBS

- Ad-EGFP

○ Ad-TRAIL

$\triangle$ Ad-TRAIL-

MRE-1-133-218
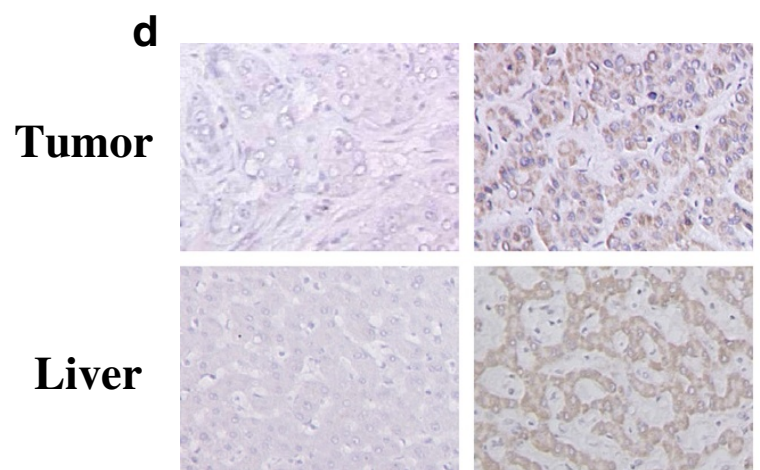

Ad-EGFP

Ad-TRAIL Ad-TRAIL-MRE-

1-133-218

Figure 4 (See legend on next page.) 
(See figure on previous page.)

Figure 4 Ad-TRAIL-MRE-1-133-218 suppressed the growth of bladder xenograft in mouse models. (a) T24 bladder cancer xenograft was established by subcutaneously injecting $2 \times 10^{6}$ cells into left flanks of female BALB/c nude mice. $1 \times 10^{9}$ pfu of different adenoviruses were treated and the tumor volumes were periodically measured. Means \pm SEM of tumor sizes were shown. The arrows indicated time-points of adenovirus injection. (b) RT-4 xenograft was established by subcutaneously injecting $1.5 \times 10^{6}$ cell into right flanks of female BALB/c nude mice. $1 \times 10^{9}$ pfu of different adenoviruses were treated and the tumor volumes were periodically measured. Means \pm SEM of tumor sizes were shown. The arrows indicated time-points of adenovirus injection. (c) BALB/c nude mice $(n=5)$ were intravenously injected with $1 \times 10^{9}$ pfu of different adenoviruses every other days for five times. On day 11, their blood was harvested for the measurement of ALT levels. Means \pm SEM of ALT serum levels were shown. (d) Histological staining was performed to detect TRAIL expression in tumor and liver section from the tumor-bearing mice after treatment of Ad-EGFP, Ad-TRAIL and Ad-TRAIL-MRE-1-133-218. The representative images were shown ( $\times 200)$.

regulated adenovirus-mediated TRAIL expression had a strong tumor-suppressing effect on bladder cancer.

To test the side effect induced by these adenoviruses, we injected Ad-EGFP, Ad-TRAIL and Ad-TRAIL-MRE-1-133218 into BALB/c mice. On day 11, their blood was collected and assayed for ALT level in serum. Ad-TRAIL treatment was found to cause an elevated level of serum ALT in mice. In contrast, Ad-TRAIL-MRE-1-133-218 did not significantly change the ALT level in the blood of mice, showing no cytotoxicity to liver cells (Figure 4c).

Also, TRAIL expression was evaluated in the tumor and liver sections from the T24 tumor-bearing mice that received the injection of Ad-EGFP, Ad-TRAIL and AdTRAIL-MRE-1-133-218. The histological staining showed that Ad-TRAIL-MRE-1-133-218 treatment resulted in high expression of TRAIL in tumors as Ad-TRAIL infection (Figure 4d). Importantly, TRAIL expression was not detected in liver section from Ad-TRAIL-MRE-1-133218-treated group, whereas Ad-TRAIL-infected mice had an extensive TRAIL expression in their livers (Figure 4d).

\section{Discussion}

In this study, we experimentally confirmed expression profiles of 20 miRNAs in bladder cancer and corresponding noncancerous bladder tissues. qPCR assay showed that all of them had lower abundance in bladder cancer in comparison with normal bladder tissue. Our results were in accordance with previous reports from other research groups. The differential expression level of these miRNAs made it feasible that their MREs can be utilized to control TRAIL expression specifically in bladder cancer cells.

Luciferase reporter assays showed that miR-1, miR-99a, miR-101, miR-133a, miR-218, miR-490-5p, miR-493 and $m i R-517 a$ only had limited suppressive effect on luciferase expression in bladder cancer cells when their MREs were applied. Further investigation indicated that MREs of miR1, miR-133a and miR-218 inhibited luciferase expression in normal bladder cells. Therefore, MREs of miR-1, miR-133a and $m i R-218$ were believed to prevent exogenous gene expression from normal bladder mucosal cells without affecting its expression in bladder cancer cells.

UPII promoter has been utilized for specific TRAIL expression in bladder cancer cells. However, gene expression controlled by this promoter is not strictly bladder cancer-specific, due to the remaining activity of UPII promoter in normal bladder mucosal cells [49]. Therefore, other strategies should be developed for preventing TRAIL expression from normal bladder cells. We employed multidisciplinary approaches to prove that TRAIL expression was greatly inhibited in Ad-TRAIL -MRE-1-133-218-infected normal bladder epithelial cells. These data demonstrated this recombinant adenovirus as a vehicle for TRAIL expression with a high bladder cancer-specificity.

As expected, Ad-TRAIL-MRE-1-133-218 induced extrinsic pathway-mediated apoptosis in bladder cancer cells, rather than normal bladder mucosal cells. Subsequent cell viability assay and animal experiments showed that AdTRAIL-MRE-1-133-218 greatly suppressed the growth of bladder cancer. More importantly, survival of normal bladder epithelial cells was almost not affected by Ad-TRAIL -MRE-1-133-218, suggesting biosafety of this MREsregulated TRAIL-expressing adenoviral vector.

To further improve the biosafety of the adenoviral vector expressing TRAIL, other MREs should also be applied to suppress the undesirable exogenous gene expression in normal tissue, such as liver. miR-122 has been extensively reported to be highly expressed in normal hepatic cells and downregulated in hepatocellular carcinoma, and thus, its MRE can be utilized to prevent cytotoxicity from liver cells [50].

TRAIL has been demonstrated as a potent anti-tumor cytokine in our study. Other therapeutic cytokines also act as candidates for cancer gene therapy, especially the natural inhibitors against signaling pathway that is critical for cancer progression. For example, DKK1 has been shown to suppress the gastric cancer progression by inhibiting $\mathrm{WNT} / \beta$ catenin pathway [51]. Our novel MRE-regulated adenoviral vector is believed to be a suitable expression vehicle for these inhibitors with high bladder cancer specificity.

\section{Conclusions}

We generated a bladder cancer-specific adenoviral vector that expressed TRAIL based on MREs of miRNAs whose levels were reduced in bladder cancer. The antitumor capacity and biosafety of this new adenoviral vector was proved by a series of experimental approaches. 
We proposed that the MREs-targeted adenovirus is a promising tool for gene therapy against bladder cancer.

\section{Additional files}

Additional file 1: Figure S1. Etoptic miRNA expression profile of T24 and RT-4 cells. Expression of miR-1, miR-99a, miR-101, miR-133a, miR-218, miR-490-5p, miR-493 and miR-517a were detected in T24 and RT-4 cells. miRNA level in noncancerous bladder tissue was regarded as standard and $U 6$ was selected as endogenous reference. Means \pm SEM of three independent experiments were shown.

Additional file 2: Figure S2. Differential expression levels of miR-1, miR$133 a$ and miR-218 between normal cells and bladder cancer Expression of miR-1, miR-133a and miR-218 were detected in HUV-EC-C and L-02 cells. miRNA level in HUV-EC-C cells was regarded as standard and U6 was selected as endogenous reference. Means \pm SEM of three independent experiments were shown.

\section{Competing interests}

The authors declare that they have no competing interests.

\section{Authors' contributions}

YZ and $Y L$ designed the study. YZ, YL, LW, HY, QW, HQ, SL, PZ, PL, QW and $X L$ performed the experiments. $Y Z$ and $Y L$ drafted the manuscript. $Y Z$ supervised the experimental work. All authors read and approved the final manuscript.

\section{Author details}

'Department of Urology, General Hospital of Chengdu Military Area Command of Chinese PLA, Chengdu 610083, Sichuan Province, People's Republic of China. ${ }^{2}$ Department of Cardiology, General Hospital of Chengdu Military Area Command of PLA, Chengdu 610083Sichuan Province, People's Republic of China. ${ }^{3}$ Department of Urology, Qingdao Municipal Hospital, Qingdao 266300Shandong Province, People's Republic of China.

Received: 26 October 2012 Accepted: 20 February 2013 Published: 26 February 2013

\section{References}

1. Jacobs BL, Lee CT, Montie JE: Bladder cancer in 2010: how far have we come? CA Cancer J Clin 2010, 60(4):244-272.

2. Voutsinas GE, Stravopodis DJ: Molecular targeting and gene delivery in bladder cancer therapy. J Buon 2009, 14(Suppl 1):S69-S78.

3. Malmstrom PU, Loskog AS, Lindqvist CA, Mangsbo SM, Fransson M, Wanders A, Gardmark T, Totterman TH: AdCD40L immunogene therapy for bladder carcinoma-the first phase 1/lla trial. Clin Cancer Res 2010, 16(12):3279-3287.

4. Vardouli L, Lindqvist C, Vlahou K, Loskog AS, Eliopoulos AG: Adenovirus delivery of human CD40 ligand gene confers direct therapeutic effects on carcinomas. Cancer Gene Ther 2009, 16(11):848-860.

5. Walczak H, Miller RE, Ariail K, Gliniak B, Griffith TS, Kubin M, Chin W, Jones J, Woodward A, Le T, Smith C, Smolak P, Goodwin RG, Rauch CT, Schuh JC, Lynch DH: Tumoricidal activity of tumor necrosis factor-related apoptosis-inducing ligand in vivo. Nat Med 1999, 5(2):157-163.

6. Muzio M, Chinnaiyan AM, Kischkel FC, O'Rourke K, Shevchenko A, Ni J, Scaffidi C, Bretz JD, Zhang M, Gentz R, Mann M, Krammer PH, Peter ME, Dixit VM: FLICE, a novel FADD-homologous ICE/CED-3-like protease, is recruited to the CD95 (Fas/APO-1) death-inducing signaling complex. Cell 1996, 85(6):817-827.

7. Zhao Y, Li Y, Wang Q, Wang L, Yang H, Li M: Increased antitumor capability of fiber-modified adenoviral vector armed with TRAIL against bladder cancers. Mol Cell Biochem 2011, 353(1-2):93-99.

8. Metwalli AR, Khanbolooki S, Jinesh G, Sundi D, Shah JB, Shrader M, Choi W Lashinger LM, Chunduru S, McConkey DJ, McKinlay M, Kamat AM: Smac mimetic reverses resistance to TRAIL and chemotherapy in human urothelial cancer cells. Cancer Biol Ther 2010, 10(9):885-892.

9. White-Gilbertson SJ, Kasman L, McKillop J, Tirodkar T, Lu P, Voelkel-Johnson C: Oxidative stress sensitizes bladder cancer cells to TRAIL mediated apoptosis by down-regulating anti-apoptotic proteins. J Urol 2009, 182(3):1178-1185.

10. Sun B, Moibi JA, Mak A, Xiao Z, Roa W, Moore RB: Response of bladder carcinoma cells to TRAIL and antisense oligonucleotide, Bcl-2 or clusterin treatments. J Urol 2009, 181(3):1361-1371.

11. Szliszka E, Mazur B, Zydowicz G, Czuba ZP, Krol W: TRAlL-induced apoptosis and expression of death receptor TRAIL-R1 and TRAIL-R2 in bladder cancer cells. Folia Histochem Cytobiol 2009, 47(4):579-585.

12. Shrader M, Pino MS, Lashinger L, Bar-Eli M, Adam L, Dinney CP, McConkey DJ: Gefitinib reverses TRAIL resistance in human bladder cancer cell lines via inhibition of AKT-mediated X-linked inhibitor of apoptosis protein expression. Cancer Res 2007, 67(4):1430-1435.

13. Li Y, Jin X, Li J, Jin X, Yu J, Sun X, Chu Y, Xu C, Li X, Wang X, Kakehi Y, Wu X: Expression of TRAIL, DR4, and DR5 in bladder cancer: correlation with response to adjuvant therapy and implications of prognosis. Urology 2012, 79(4):968 e967-968 e915.

14. Zhai Z, Wang Z, Fu S, Lu J, Wang F, Li R, Zhang H, Li S, Hou Z, Wang H, Rodriguez R: Antitumor effects of bladder cancer-specific adenovirus carrying E1A-androgen receptor in bladder cancer. Gene Ther 2012, 19(11):1065-1074.

15. Wang D, Wang Z, Tian J, He X, Chowdhury WH, Zhang X, Li S, Rodriguez R: Prostate stem cell antigen enhancer and uroplakin II promoter based bladder cancer targeted tissue-specific vector. Urol Oncol 2010, 28(2):164-169.

16. Zhu H, Zhang ZA, Xu C, Huang G, Zeng X, Wei S, Zhang Z, Guo Y: Targeting gene expression of the mouse uroplakin II promoter to human bladder cells. Urol Res 2003, 31(1):17-21.

17. Catto JW, Alcaraz A, Bjartell AS, De Vere WR, Evans CP, Fussel S, Hamdy FC, Kallioniemi O, Mengual L, Schlomm T, Visakorpi T: MicroRNA in prostate, bladder, and kidney cancer: a systematic review. Eur Urol 2011, 59(5):671-681.

18. Yamasaki T, Yoshino H, Enokida H, Hidaka H, Chiyomaru T, Nohata N, Kinoshita T, Fuse M, Seki N, Nakagawa M: Novel molecular targets regulated by tumor suppressors microRNA-1 and microRNA-133a in bladder cancer. Int J Oncol 2012, 40(6):1821-1830.

19. Yoshino H, Enokida H, Chiyomaru T, Tatarano S, Hidaka H, Yamasaki T, Gotannda T, Tachiwada T, Nohata N, Yamane T, Seki N, Nakagawa M: Tumor suppressive microRNA-1 mediated novel apoptosis pathways through direct inhibition of splicing factor serine/arginine-rich 9 (SRSF9/SRp30c) in bladder cancer. Biochem Biophys Res Commun 2012, 417(1):588-593.

20. Yoshino H, Chiyomaru T, Enokida H, Kawakami K, Tatarano S, Nishiyama K, Nohata N, Seki N, Nakagawa M: The tumour-suppressive function of miR-1 and miR-133a targeting TAGLN2 in bladder cancer. Br J Cancer 2011, 104(5):808-818.

21. Chiyomaru T, Enokida H, Kawakami K, Tatarano S, Uchida Y, Kawahara K, Nishiyama K, Seki N, Nakagawa M: Functional role of LASP1 in cell viability and its regulation by microRNAs in bladder cancer. Urol Oncol, 30(4):434-443.

22. Han Y, Chen J, Zhao X, Liang C, Wang Y, Sun L, Jiang Z, Zhang Z, Yang R, Chen J, Li Z, Tang A, Li X, Ye J, Guan Z, Gui Y, Cai Z: MicroRNA expression signatures of bladder cancer revealed by deep sequencing. PLoS One 2011, 6(3):e18286.

23. Song T, Xia W, Shao N, Zhang X, Wang C, Wu Y, Dong J, Cai W, Li H: Differential miRNA expression profiles in bladder urothelial carcinomas. Asian Pac J Cancer Prev 2010, 11(4):905-911.

24. Kottakis F, Polytarchou C, Foltopoulou P, Sanidas I, Kampranis SC, Tsichlis PN: FGF-2 regulates cell proliferation, migration, and angiogenesis through an NDY1/KDM2B-miR-101-EZH2 pathway. Mol Cell 2011, 43(2):285-298

25. Friedman JM, Liang G, Liu CC, Wolff EM, Tsai YC, Ye W, Zhou X, Jones PA: The putative tumor suppressor microRNA-101 modulates the cancer epigenome by repressing the polycomb group protein EZH2. Cancer Res 2009, 69(6):2623-2629.

26. Baffa R, Fassan M, Volinia S, O'Hara B, Liu CG, Palazzo JP, Gardiman M, Rugge $M$, Gomella LG, Croce CM, Rosenberg A: MicroRNA expression profiling of human metastatic cancers identifies cancer gene targets. J Pathol 2009, 219(2):214-221

27. Huang L, Luo J, Cai Q, Pan Q, Zeng H, Guo Z, Dong W, Huang J, Lin T: MicroRNA-125b suppresses the development of bladder cancer by targeting E2F3. Int J Cancer 2011, 128(8):1758-1769.

28. Uchida Y, Chiyomaru T, Enokida H, Kawakami K, Tatarano S, Kawahara K, Nishiyama K, Seki N, Nakagawa M: MiR-133a induces apoptosis through 
direct regulation of GSTP1 in bladder cancer cell lines. Urol Oncol 2011, 31(1):115-123.

29. Chiyomaru T, Enokida H, Tatarano S, Kawahara K, Uchida Y, Nishiyama K, Fujimura L, Kikkawa N, Seki N, Nakagawa M: miR-145 and miR-133a function as tumour suppressors and directly regulate FSCN1 expression in bladder cancer. Br J Cancer 2010, 102(5):883-891.

30. Ichimi T, Enokida H, Okuno Y, Kunimoto R, Chiyomaru T, Kawamoto K, Kawahara K, Toki K, Kawakami K, Nishiyama K, Tsujimoto G, Nakagawa M, Seki N: Identification of novel microRNA targets based on microRNA signatures in bladder cancer. Int J Cancer 2009, 125(2):345-352.

31. Villadsen SB, Bramsen JB, Ostenfeld MS, Wiklund ED, Fristrup N, Gao S, Hansen TB, Jensen TI, Borre M, Orntoft TF, Dyrskjot L, Kjems J: The miR-143 /-145 cluster regulates plasminogen activator inhibitor-1 in bladder cancer. Br J Cancer 2012, 106(2):366-374.

32. Song T, Zhang X, Wang C, Wu Y, Dong J, Gao J, Cai W, Hong B: Expression of miR-143 reduces growth and migration of human bladder carcinoma cells by targeting cyclooxygenase-2. Asian Pac J Cancer Prev 2011, 12(4):929-933.

33. Noguchi S, Mori T, Hoshino Y, Maruo K, Yamada N, Kitade Y, Naoe T, Akao Y: MicroRNA-143 functions as a tumor suppressor in human bladder cancer T24 cells. Cancer Lett 2011, 307(2):211-220.

34. Ostenfeld MS, Bramsen JB, Lamy P, Villadsen SB, Fristrup N, Sorensen KD, Ulhoi B, Borre M, Kjems J, Dyrskjot L, Orntoft TF: miR-145 induces caspasedependent and -independent cell death in urothelial cancer cell lines with targeting of an expression signature present in Ta bladder tumors. Oncogene 2010, 29(7):1073-1084.

35. Fei X, Qi M, Wu B, Song Y, Wang Y, Li T: MicroRNA-195-5p suppresses glucose uptake and proliferation of human bladder cancer T24 cells by regulating GLUT3 expression. FEBS Lett 2012, 586(4):392-397.

36. Shatseva T, Lee DY, Deng Z, Yang BB: MicroRNA miR-199a-3p regulates cell proliferation and survival by targeting caveolin-2. J Cell Sci 2011, 124(Pt 16):2826-2836.

37. Wiklund ED, Bramsen JB, Hulf T, Dyrskjot L, Ramanathan R, Hansen TB, Villadsen SB, Gao S, Ostenfeld MS, Borre M, Peter ME, Orntoft TF, Kjems J, Clark SJ: Coordinated epigenetic repression of the miR-200 family and miR-205 in invasive bladder cancer. Int I Cancer 2011, 128(6):1327-1334.

38. Adam L, Zhong M, Choi W, Qi W, Nicoloso M, Arora A, Calin G, Wang H, Siefker-Radtke A, McConkey D, Bar-Eli M, Dinney C: miR-200 expression regulates epithelial-to-mesenchymal transition in bladder cancer cells and reverses resistance to epidermal growth factor receptor therapy. Clin Cancer Res 2009, 15(16):5060-5072.

39. Bo J, Yang G, Huo K, Jiang H, Zhang L, Liu D, Huang Y: microRNA-203 suppresses bladder cancer development by repressing bcl-w expression. Febs J 2011, 278(5):786-792.

40. Gottardo F, Liu CG, Ferracin M, Calin GA, Fassan M, Bassi P, Sevignani C, Byrne D, Negrini M, Pagano F, Gomella LG, Croce CM, Baffa R: Micro-RNA profiling in kidney and bladder cancers. Urol Oncol 2007, 25(5):387-392.

41. Tatarano S, Chiyomaru T, Kawakami K, Enokida H, Yoshino H, Hidaka H, Yamasaki T, Kawahara K, Nishiyama K, Seki N, Nakagawa M: miR-218 on the genomic loss region of chromosome $4 \mathrm{p} 15.31$ functions as a tumor suppressor in bladder cancer. Int J Oncol 2011, 39(1):13-21.

42. Han Y, Chen J, Zhao X, Liang C, Wang Y, Sun L, Jiang Z, Zhang Z, Yang R, Chen J, Li Z, Tang A, Li X, Ye J, Guan Z, Gui Y, Cai Z: MicroRNA expression signatures of bladder cancer revealed by deep sequencing. PLoS One, 6(3):e18286

43. Ueno K, Hirata H, Majid S, Yamamura S, Shahryari V, Tabatabai ZL, Hinoda Y, Dahiya R: Tumor suppressor microRNA-493 decreases cell motility and migration ability in human bladder cancer cells by downregulating RhoC and FZD4. Mol Cancer Ther 2012, 11(1):244-253.

44. Yoshitomi T, Kawakami K, Enokida H, Chiyomaru T, Kagara I, Tatarano S, Yoshino H, Arimura H, Nishiyama K, Seki N, Nakagawa M: Restoration of miR-517a expression induces cell apoptosis in bladder cancer cell lines. Oncol Rep 2011, 25(6):1661-1668.

45. Tatarano S, Chiyomaru T, Kawakami K, Enokida H, Yoshino H, Hidaka H, Nohata N, Yamasaki T, Gotanda T, Tachiwada T, Seki N, Nakagawa M: Novel oncogenic function of mesoderm development candidate 1 and its regulation by MiR-574-3p in bladder cancer cell lines. Int J Oncol 2012, 40(4):951-959

46. Hirata H, Hinoda Y, Ueno K, Shahryari V, Tabatabai ZL, Dahiya R: MicroRNA1826 targets VEGFC, beta-catenin (CTNNB1) and MEK1 (MAP2K1) in human bladder cancer. Carcinogenesis 2012, 33(1):41-48.
47. Woodman JR, Mansfield K, Lazzaro VA, Lynch W, Burcher E, Moore KH: Immunocytochemical characterisation of cultures of human bladder mucosal cells. BMC Urol 2011, 11:5.

48. He X, Liu J, Yang C, Su C, Zhou C, Zhang Q, Li L, Wu H, Liu X, Wu M, Qian Q: 5/35 fiber-modified conditionally replicative adenovirus armed with p53 shows increased tumor-suppressing capacity to breast cancer cells. Hum Gene Ther 2011, 22(3):283-292.

49. Lin JH, Wu XR, Kreibich G, Sun TT: Precursor sequence, processing, and urothelium-specific expression of a major 15-kDa protein subunit of asymmetric unit membrane. J Biol Chem 1994, 269(3):1775-1784.

50. Ma L, Liu J, Shen J, Liu L, Wu J, Li W, Luo J, Chen Q, Qian C: Expression of miR-122 mediated by adenoviral vector induces apoptosis and cell cycle arrest of cancer cells. Cancer Biol Ther 2010, 9(7):554-561.

51. Wang B, Liu J, Ma LN, Xiao HL, Wang YZ, Li Y, Wang Z, Fan L, Lan C, Yang M, Hu L, Wei Y, Bian XW, Chen D, Wang J: Chimeric 5/35 adenovirus-mediated Dickkopf-1 overexpression suppressed tumorigenicity of CD44(+) gastric cancer cells via attenuating Wnt signaling. J Gastroenterol 2012. Epub ahead of print

\section{doi:10.1186/1756-9966-32-10}

Cite this article as: Zhao et al:: microRNA response elements-regulated TRAIL expression shows specific survival-suppressing activity on bladder cancer. Journal of Experimental \& Clinical Cancer Research 2013 32:10.

\section{Submit your next manuscript to BioMed Central and take full advantage of:}

- Convenient online submission

- Thorough peer review

- No space constraints or color figure charges

- Immediate publication on acceptance

- Inclusion in PubMed, CAS, Scopus and Google Scholar

- Research which is freely available for redistribution 